\title{
Cytochrome P450 3A5 is highly expressed in normal prostate cells but absent in prostate cancer
}

\author{
S Leskelä ${ }^{1}$, E Honrado $^{2}$, C Montero-Conde $^{1}{ }^{\text {, I Landa }}{ }^{1}$, A Cascón ${ }^{1}$, R Letón ${ }^{1}$, \\ P Talavera ${ }^{3}$, J M Cózar $^{4}$, A Concha $^{3}$, M Robledo $^{1}$ and C Rodríguez-Antona ${ }^{1}$
}

\author{
${ }^{1}$ Hereditary Endocrine Cancer Group and ${ }^{2}$ Human Genetics Group, Human Cancer Genetics Programme, Spanish National Cancer \\ Center (CNIO), C/Melchor Fernández Almagro, 3, 28029 Madrid, Spain \\ ${ }^{3}$ Department of Anatomic Pathology and Tumor Bank and ${ }^{4}$ Department of Urology, Hospital Virgen de las Nieves, Avenida \\ Constitución 100, 18012 Granada, Spain \\ (Correspondence should be addressed to C Rodríguez-Antona; Email: cristina.rodriguez-antona@cnio.es)
}

\begin{abstract}
Testosterone is essential for the growth and function of the luminal prostate cells, but it is also critical for the development of prostate cancer, which in the majority of the cases derives from luminal cells. Cytochrome P450 3A (CYP3A) enzymes hydroxylate testosterone and dehydroepiandrosterone to less active metabolites, which might be the basis for the association between CYP3A polymorphisms and prostate cancer. However, it is unknown whether the CYP3A enzymes are expressed at relevant levels in the prostate and which polymorphisms could affect this tissue-specific CYP3A activity. Thus, we measured CYP3A4, CYP3A5, CYP3A7, and CYP3A43 mRNA in 14 benign prostatic hyperplasias and ten matched non-tumoral/tumoral prostate samples. We found that CYP3A5 mRNA in non-tumoral prostate tissue was $10 \%$ of the average amount of liver samples, whereas the expression of the other CYP3A genes was much lower. Similarly to liver, CYP3A5*3 polymorphism decreased CYP3A5 mRNA content 13-fold. CYP3A5 protein was detected in non-tumoral prostate microsomes by western blot, and immunohistochemistry (IHC) localized CYP3A5 exclusively in the basolateral prostate cells. In contrast to the normal tissue, IHC and RT-PCR showed that tumoral tissue lacked CYP3A5 expression. In conclusion, prostate basolateral cells express high levels of CYP3A5 which dramatically decrease in tumoral tissue. This finding supports an endogenous function of CYP3A5 related to the metabolism of intra-prostatic androgens and cell growth, and that polymorphisms affecting CYP3A5 activity may result in altered prostate cancer risk and aggressiveness.
\end{abstract}

Endocrine-Related Cancer (2007) 14 645-654

\section{Introduction}

Prostate cancer is the second leading cause of cancer death in men, and both genetic and environmental factors have been shown to be important for the development of this disease (Novelli et al. 2004). More than $95 \%$ of the prostate tumors derive from luminal cells, which grow in an androgen-dependent manner through androgen receptor activation. There are three distinct glandular regions in the human prostate gland: peripheral, central, and transitional zone comprising: 70,30 , and $5 \%$ of the normal glandular prostate mass respectively (Villers et al. 1991). The peripheral zone is the site of origin of most carcinomas and it is the most susceptible region to inflammation, the central zone is resistant to both carcinoma and inflammation, while the transitional zone is the site of origin of benign nodular hyperplasia and rarely carcinomas (McNeal 1969, 1978, McNeal et al. 1988a,b).

Testosterone is essential for prostate cancer development (Feldman \& Feldman 2001) and genetic changes affecting the expression/activity of the enzymes metabolizing androgens can influence prostate cancer progression (Makridakis et al. 1997, 1999, Park et al. 2006). For this reason, several studies have focused on cytochromes P450 3A (CYP3As) polymorphisms, the rationale being that, in addition to the prominent role of 
CYP3A enzymes in the metabolism of over $50 \%$ of all clinical drugs (Li et al. 1995, Thummel \& Wilkinson 1998, Rodriguez-Antona \& Ingelman-Sundberg 2006), CYP3A enzymes also metabolize testosterone and dehydroepiandrosterone (DHEA) to hydroxy-metabolitesless active and easier to eliminate (Ohmori et al. 1998, Kamdem et al. 2004, Miller et al. 2004). Thus, an alteration in the CYP3A prostate activity could change the local testosterone levels and alter the tissue-specific androgen effects, prostate growth, and cancer development.

The CYP3A subfamily comprises four members: CYP3A4, CYP3A5, CYP3A7, and CYP3A43, which have similar substrate specificities but different expression patterns. CYP3A4 is the predominant form in liver and small intestine (Lin et al. 2002). CYP3A5 is also present in liver and gastrointestinal tract but at lower levels and in a bimodal manner due to $C Y P 3 A 5 * 3$, $C Y P 3 A 5^{*} 6$, and $C Y P 3 A 5^{*} 7$ defective alleles, the last two present only in Africans (Hustert et al. 2001, Kuehl et al. 2001, Lin et al. 2002, Lee et al. 2003). CYP3A7 is primarily expressed in fetal stages, but $C Y P 3 A 7 * 1 C$ allele triggers its expression in adult stages (Kuehl et al. 2001, Burk et al. 2002, Sim et al. 2005). CYP3A43 mRNA has been detected mainly in the prostate, testis, and liver, but at relatively low levels (Domanski et al. 2001, Westlind et al. 2001). With respect to the CYP3A prostate expression, Murray et al. (1995b) found no CYP3A protein in normal prostate tissue, but they detected expression in $61 \%$ of tumor samples. In contrast, Moilanen et al. (2007), focusing specifically on CYP3A5, detected CYP3A5 protein in normal and tumoral prostate tissue, but the defective CYP $3 A 5 * 3$ allele seemed to have no effect on protein expression. On the other hand, Di Paolo et al. (2005) found higher amounts of CYP3A4 than CYP3A5 protein in normal tissue and Zhang et al. (2006) found both CYP3A4 and CYP3A5 proteins in most tumoral tissues analyzed. With respect to the mRNA content, CYP3A4, CYP3A5, CYP3A7, and CYP3A43 mRNAs have been detected in normal and tumoral prostate tissue in different works using different techniques (Finnstrom et al. 2001, Stamey et al. 2001, Westlind et al. 2001, Koch et al. 2002). Despite the unclear expression profile and role of the CYP3A enzymes in prostate, several studies have shown an association between different $C Y P 3 A$ single nucleotide polymorphisms (SNPs), mainly $C Y P 3 A 4 * 1 B$, and prostate cancer risk and/or aggressiveness, suggesting that CYP3A enzymes may play an important role in prostate cell growth (Rebbeck et al. 1998, Paris et al. 1999, Plummer et al. 2003, Loukola et al. 2004, Bangsi et al. 2006). However, the high degree of ethnicspecific linkage disequilibrium among all CYP $3 A 4$,
CYP3A5, and CYP3A7 SNPs prevents the identification of the relevant enzyme that could be involved in intraprostatic androgen metabolism and cancer development (Thompson et al. 2004, 2006).

Thus, this study was aimed at identifying the CYP3A enzyme(s) expressed at relevant levels in normal and tumoral prostate tissue and the mechanisms affecting its expression. For that purpose we used quantitative RT-PCR, western blot, and IHC analysis in a panel of normal and matched tumoral prostate samples.

\section{Materials and methods}

\section{Human samples}

The study included 14 benign prostatic hyperplasia (BPH) tissues and ten matched non-tumoral/tumoral prostate tissues, both frozen and paraffin embedded. Specimens were obtained from the Tumor Bank of the Department of Pathology, Universitary Hospital Virgen de las Nieves, Granada. Twenty-five additional tumoral prostate paraffin sections were obtained from the Department of Pathology from the Hospital of Leon. The specimens were selected from radical prostatectomy by an expert pathologist. Hematoxylinand eosin-stained sections were examined by a pathologist to determine the percentage of cancer cells in the tumor samples. The Gleason score and $\mathrm{T}$ stage of the frozen samples are shown in Table 1. The paraffin samples from the Hospital of Leon had Gleason scores between six and nine and the $\mathrm{T}$ stage was T2 or T3 in all cases. In addition, seven liver samples were used for RT-PCR mRNA quantification.

\section{DNA isolation and genotyping}

DNA was isolated from the frozen tissue samples using Qiagen DNeasy tissue kit (Qiagen, Valencia, CA, USA) according to manufacturer's protocol. CYP3A5*3 polymorphism (rs776746, 6986A $>\mathrm{G}$, the reference sequence corresponds to accession number NG 000004.2) was analyzed by PCR using specific primers (Supplementary Table 1, which can be viewed online at http://erc.endocrinology-journals.org/supplemental/) and direct sequencing (sequencer 3730, Applied Biosystems, Foster City, CA, USA). The PCR was initiated by an initial step for 2 min at $94{ }^{\circ} \mathrm{C}$, followed by 36 cycles of $30 \mathrm{~s}$ at $94{ }^{\circ} \mathrm{C}, 30 \mathrm{~s}$ at $58^{\circ} \mathrm{C}$, and $45 \mathrm{~s}$ at $72{ }^{\circ} \mathrm{C}$, and completed with $7 \mathrm{~min}$ at $72{ }^{\circ} \mathrm{C}$.

\section{RNA isolation and real-time quantitative RT-PCR}

RNA was isolated from the frozen tissue using TRI reagent (Molecular Research Center Inc., Cincinnati, 
Table 1 Characteristics of the human prostate samples

\begin{tabular}{|c|c|c|c|c|c|c|}
\hline $\begin{array}{l}\text { Prostate } \\
\text { sample }\end{array}$ & Age (years) & Tissue & Gleason score & T stage $^{a}$ & Relapse $^{\mathrm{b}}$ & CYP3A5 genotype \\
\hline 112 & 63 & $\mathrm{BPH}$ & - & - & - & *1/*3 \\
\hline 113 & 66 & $\mathrm{BPH}$ & - & - & - & *3/*3 \\
\hline 114 & 70 & $\mathrm{BPH}$ & - & - & - & *1/*3 \\
\hline 116 & 64 & $\mathrm{BPH}$ & - & - & - & ${ }^{*} 3 /{ }^{*} 3$ \\
\hline 118 & 76 & $\mathrm{BPH}$ & - & - & - & *3/*3 \\
\hline 120 & 59 & $\mathrm{BPH}$ & - & - & - & *1/*3 \\
\hline 121 & 77 & $\mathrm{BPH}$ & - & - & - & ${ }^{*} 3 /{ }^{*} 3$ \\
\hline 122 & 80 & $\mathrm{BPH}$ & - & - & - & ${ }^{*} 3 /{ }^{*} 3$ \\
\hline 123 & 74 & $\mathrm{BPH}$ & - & - & - & ${ }^{*} 3 /{ }^{*} 3$ \\
\hline 124 & 62 & $\mathrm{BPH}$ & - & - & - & ${ }^{*} 1 / * 3$ \\
\hline 125 & 70 & $\mathrm{BPH}$ & - & - & - & ${ }^{*} 3 /{ }^{*} 3$ \\
\hline 126 & 68 & $\mathrm{BPH}$ & - & - & - & ${ }^{*} 3 /{ }^{*} 3$ \\
\hline 127 & 76 & $\mathrm{BPH}$ & - & - & - & $* 3 /{ }^{*} 3$ \\
\hline 002 & 61 & $\mathrm{~T}+\mathrm{NT}^{\mathrm{c}}$ & $3+3$ & T2C & $\mathrm{N}(22)$ & ${ }^{*} 3 /{ }^{*} 3$ \\
\hline 019 & 69 & $\mathrm{~T}+\mathrm{NT}$ & $3+3$ & Т3В & Y (19) & ${ }^{*} 3 /{ }^{*} 3$ \\
\hline 049 & 66 & $\mathrm{~T}+\mathrm{NT}$ & $3+4$ & T3A & $Y(18)$ & ${ }^{*} 3 /{ }^{*} 3$ \\
\hline 060 & 61 & $\mathrm{~T}+\mathrm{NT}$ & $3+3$ & T3A & N (29) & ${ }^{*} 3 /{ }^{*} 3$ \\
\hline 074 & 69 & $\mathrm{~T}+\mathrm{NT}$ & $3+4$ & T3A & $Y(16)$ & ${ }^{*} 3 /{ }^{*} 3$ \\
\hline 137 & 67 & $\mathrm{~T}+\mathrm{NT}$ & $3+3$ & T2B & $N(25)$ & ${ }^{*} 3 /{ }^{*} 3$ \\
\hline 143 & 53 & $\mathrm{~T}+\mathrm{NT}$ & $3+2$ & T2B & N (14) & ${ }^{*} 1 / * 3$ \\
\hline 146 & 61 & $\mathrm{~T}+\mathrm{NT}$ & $3+4$ & T3A & $N(23)$ & ${ }^{*} 3 /{ }^{*} 3$ \\
\hline 148 & 71 & $\mathrm{~T}+\mathrm{NT}$ & $3+3$ & T2B & $N(23)$ & ${ }^{*} 3 /{ }^{*} 3$ \\
\hline 169 & 51 & $\mathrm{~T}+\mathrm{NT}$ & $3+3$ & T2B & N (14) & ${ }^{*} 3 /{ }^{*} 3$ \\
\hline
\end{tabular}

aTumor clinical classification corresponds to the 6th edition of the AJCC/UICC TNM classification of malignant tumors.

${ }^{\mathrm{b}}$ After surgery, PSA levels below $0.1 \mathrm{mg} / \mathrm{ml}$ indicate no relapse $(\mathrm{N})$ and PSA levels above $0.1 \mathrm{mg} / \mathrm{ml}$ indicate relapse $(\mathrm{Y})$.

The months of follow-up or time to relapse respectively are shown in brackets.

${ }^{\mathrm{C}} \mathrm{T}$ stands for tumoral and NT stands for non-tumoral tissue in the matched samples.

OH, USA). One microgram of the total RNA was reverse transcribed using Superscript II Reverse Transcriptase (Invitrogen) and an oligo dT14 primer following manufacturer's instructions. All the normal tissue samples as well as all carcinomas were from the peripheral zone, while the benign hyperplasia samples were from the transitional zone.

The amounts of CYP3A4, CYP3A5, CYP3A7, and CYP3A43 mRNAs were quantified by real-time PCR with the Sequence Detection System 7900HT (Applied Biosystems), using specific primers and probes (Supplementary Table 2, which can be viewed online at http:// erc.endocrinology-journals.org/supplemental/) at a final concentration of 0.9 and $0.2 \mu \mathrm{M}$ respectively, and the Universal Master Mix (PE Applied Biosystems). The amplification conditions consisted of an initial step at $95^{\circ} \mathrm{C}$ for $10 \mathrm{~min}$, followed by 50 cycles of $15 \mathrm{~s}$ at $95^{\circ} \mathrm{C}$ and $1 \mathrm{~min}$ at $60{ }^{\circ} \mathrm{C}$. Standard curves were generated with serial $1 / 10$ dilutions of a pool of seven liver cDNAs. For CYP3A5 mRNA quantification, a pool of two $C Y P 3 A 5^{*} 1 / * 3$ liver cDNAs were used for the standard curve construction and a pool of four $C Y P 3 A 5 * 3 / * 3$ liver cDNAs were included for quantification. Normalization was carried out with the internal standard $\beta$-glucuronidase (GUS). Negative controls were present in all series of PCR and all assays were carried out in triplicates.

\section{Subcellular fractionation of human prostate tissues}

Five BPH samples were used to obtain microsomal fractions (samples 112, 113, 114, 118, and 124). The tissues were homogenized with a glass homogenizer in four volumes of ice-cold $50 \mathrm{mM}$ Tris- $\mathrm{HCl}, \mathrm{pH} 7.4$ containing $0.25 \mathrm{M}$ sucrose and protease inhibitors. The resulting homogenate was centrifuged at $10000 \mathrm{~g}$ for $20 \mathrm{~min}$ at $4^{\circ} \mathrm{C}$, followed by centrifugation at $100000 \mathrm{~g}$ for $1 \mathrm{~h}$ at $4{ }^{\circ} \mathrm{C}$. The pellet was washed and resuspended in $0.1 \mathrm{M}$ PBS, pH 7.4 with $10 \%$ glycerol and protease inhibitors (Roche). Protein content was measured by Bio-Rad protein assay (Bio-Rad laboratories). In all cases we obtained sufficient amount of microsomal fraction to perform immunoblot analyses (in average $1.6 \mathrm{mg}$ microsomal protein/g of starting material).

\section{Immunoblot analysis}

Prostate microsomal proteins were separated by $9 \%$ SDS-PAGE using the Mini-PROTEAN III electrophoresis cell (Bio-Rad) and transferred to 
polyvinylidene fluoride membranes (Immobilon-P Membrane, Millipore, Billerica, MA, USA). Equal loading of proteins was verified by Ponceau $S$ staining. The membranes were blocked and then incubated with an antihuman CYP3A5 antibody (ab22692, Abcam, Cambridge, UK) following manufacturer's instructions. This is a commercial polyclonal antibody raised against a synthetic hexapeptide including the C-terminal of CYP3A5 and reacting exclusively with CYP3A5, effective both for western blot and immunohistochemistry (IHC). After washing, the membranes were incubated with a goat anti-rabbit (DAKO, Copenhagen, Denmark) secondary antibody, and the corresponding horseradish peroxide signal was visualized using SuperSignal Femto substrate (Pierce, Rockford, IL, USA) and BiomaxLight membranes (Kodak). The CYP3A5 content was determined from standard curves derived from human CYP3A5 + P450 reductase Supersomes (BD Biosciences, San Jose, CA, USA). The detection limit under these conditions was of 0.025 pmol CYP3A5/mg microsomal protein.

\section{Immunohistochemistry (IHC)}

Formalin-fixed, paraffin-embedded tissue sections were immunohistochemically stained using a polyclonal anti-CYP3A5 antibody (1:20000, ab22692, Abcam). Immunohistochemical staining was performed by the DAKO Envision system (DAKO) with a heat induced, antigen retrieval step. Sections from the paraffinembedded tissue were immersed in boiling $10 \mathrm{mM}$ sodium citrate at $\mathrm{pH} 6.5$ for $2 \mathrm{~min}$ in a pressure cooker and finally proteinase $\mathrm{K}$ was added for $10 \mathrm{~min}$ at room temperature. For the frozen tissues $5 \mu \mathrm{m}$ sections were cut with a cryostat, dehydrated in $70 \%$ ethanol over night, fixed in acetone for $10 \mathrm{~min}$, and stained with the same antibody and dilution used for the paraffinembedded tissue, without antigen retrieval. Kidney samples were used to optimize the signal detection and the specificity of the signal was assured by following the same immunohistochemical staining procedure but without adding CYP3A5 antibody (Fig. 3E). The results were analyzed by two experienced pathologist (E H and A C) and cytokeratin $34 \beta \mathrm{E} 12$ was used as a marker for prostate basolateral cells.

\section{Results}

\section{CYP3A5 is expressed at high levels in normal prostate tissue and its expression is influenced by $C Y P 3 A 5^{\star} 3$ polymorphism}

We used quantitative RT-PCR to measure the CYP3As mRNA content in 24 non-tumoral prostate tissues and compared it with the expression of a pool of livers, which is the tissue with the highest CYP3A content. There were no significant differences in the CYP3As expression between the $14 \mathrm{BPH}$ (from the transitional zone) and the ten non-tumoral (from the peripheral zone) prostate samples, suggesting that the $C Y P 3 A$ expression is not dependent on the prostate zone. Thus, the 24 tissues were analyzed together. We found that CYP3A5 mRNA content in prostate was the highest (10\% hepatic levels), while CYP3A4, CYP3A7, and CYP3A43 mRNA content was much lower $(0.0004$, 0.05 , and $0.15 \%$ of the liver respectively), and that more than seven PCR amplification cycles separated CYP3A5 content from the other CYP3A isoform (Fig. 1). The prostate CYP3A5 content represented from 7.9 to $69 \%$ of the hepatic levels, depending on the liver used for comparison. For CYP3A4 and CYP3A7 the maximum values were below $1 \%$, while for CYP3A43, due to a very low CYP3A43 content in one of the livers up to $5.4 \%$ could be observed. Nevertheless the main CYP3A enzyme in prostate was CYP3A5.

CYP3A5 showed a 16-fold inter-sample variability in the 24 prostate cases studied. In the liver, CYP3A5 expression is influenced to a large extent by $C Y P 3 A 5 * 3$ polymorphism which, with a $90 \%$ frequency in Caucasians, creates a cryptic consensus splice site in intron 3. $C Y P 3 A 5 * 3$ results mainly in splice variant

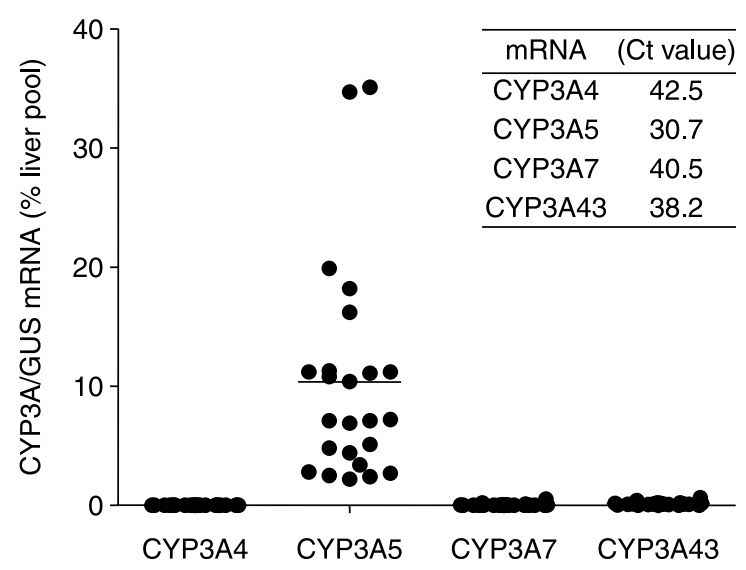

Figure 1 CYP3A5 mRNA is expressed at relevant levels in prostate normal tissue. The mRNA content of CYP3A4, CYP3A5, CYP3A7, and CYP3A43 was measured by quantitative RT-PCR, as described in Materials and methods section, in 10 normal and $14 \mathrm{BPH}$ prostate tissues. For CYP3A5 the primers used measured the total amount of CYP3A5 mRNA (correctly plus alternatively spliced mRNA). The amount of CYP3A mRNA was normalized with the GUS mRNA content in each sample. The quantification was performed using a pool of seven liver cDNAs and the results are expressed as percentage of the liver expression. The average number of PCR cycles needed to amplify each isoform above the threshold $\left(C_{t}\right)$ is shown in the insert. 
mRNAs that contain a premature termination codon (amino acid 102) and only a small amount of correctly spliced $C Y P 3 A 5 \mathrm{mRNA}$ and protein is produced. Thus, to determine the influence of $C Y P 3 A 5 * 3$ in prostate, we performed CYP3A5 RT-PCR analysis using liver samples with different $C Y P 3 A 5$ genotypes and quantified both the correctly spliced and the total (correctly spliced plus alternatively spliced) CYP3A5 mRNAs. Similar to liver, $C Y P 3 A 5 * 3 / * 3$ prostate samples had lower CYP3A5 mRNA content than those $C Y P 3 A 5 * 1 / * 3$ (3.3- and 13-fold lower total and correctly spliced CYP3A5 mRNA in prostate compared with 2.8 - and 10-fold difference in the liver samples respectively; Fig. 2A). The CYP3A5 total mRNA content of the prostate samples was $25 \%$ of the average amount in liver samples with the same CYP3A5 genotype (Fig. 2A upper panel), while for correctly spliced mRNA it was $15 \%$ (Fig. 2A lower panel).

To further characterize the expression of CYP3A5 in prostate, we performed a western blot analysis using a
CYP3A5-specific antibody. As shown in Fig. 2B, CYP3A5 protein was detected in only some BPH microsomal fractions. Although there was not a strong correlation between CYP3A5 mRNA and protein content, the strongest signals corresponded to CYP $3 A 5 * 1 / * 3$ samples. The amount of CYP3A5 protein in sample 124 (with the highest expression) was of 0.15 pmol CYP3A5 per mg of total microsomal protein, which is much lower than CYP3A5 hepatic levels. However, this data should be referred to the prostate cells expressing CYP3A5, thus, it is important to determine CYP3A5 localization.

\section{CYP3A5 is expressed exclusively in the basolateral cells of the prostate}

IHC was used to determine the localization of CYP3A5 in the prostate tissue. Both in frozen and paraffined tissues, CYP3A5 staining was exclusively localized in the basolateral cells in the 24 non-tumoral samples
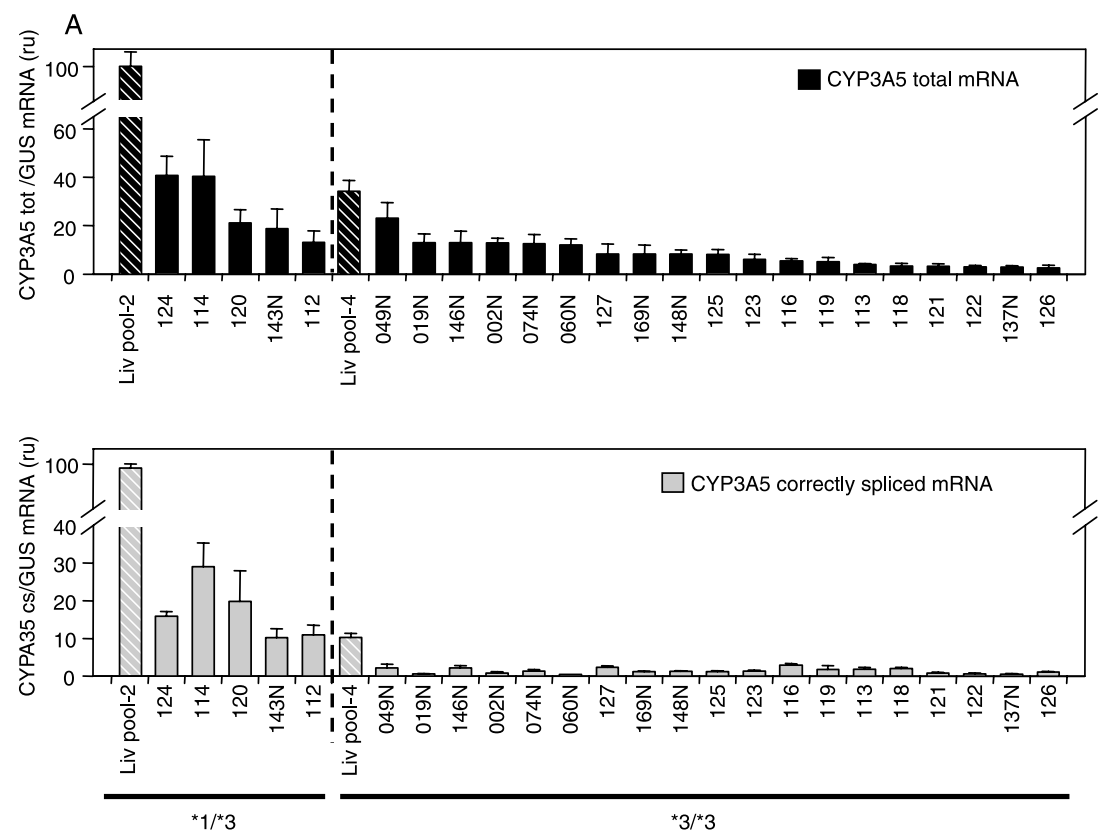

B

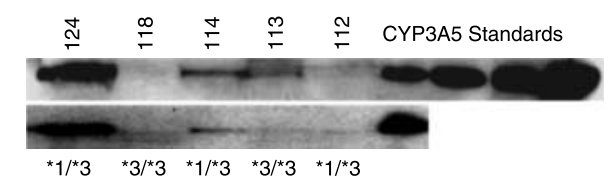

Figure 2 CYP3A5 mRNA and protein content in human prostate. (A) The amounts of total and correctly spliced CYP3A5 mRNA were quantified in 24 prostate samples and two liver pools using specific primers: the black bars correspond to total (tot) CYP3A5 mRNA while the gray bars correspond to correctly spliced (cs) mRNA. The CYP3A5 genotype of the samples is shown below as ‘* $1 /{ }^{*} 3$ ' (five prostate samples and one pool of two livers) and '*3/*3', (19 prostate samples and 1 pool of 4 livers). The liver pools are shown with dashed bars. Relative units (ru); liver pool (Liv pool). (B) CYP3A5 protein expression was analyzed by western blotting in BPH microsomes (samples 112,113,114, 118, and 124) using a CYP3A5-specific antibody and commercial CYP3A5 Supersomes were used as standards for quantification. Two independent experiments are shown. The CYP3A5 genotype of each prostate sample is indicated below. 
analyzed, specifically in the cytoplasmatic region, as expected for a microsomal protein (Fig. 3A and B). In contrast, stromal and luminal cells did not express CYP3A5. The prostate basolateral cell marker cytokeratin 34ßE12 was used to confirm CYP3A5 basal localization (Fig. 3F). The effect of $C Y P 3 A 5^{*} 3$ was not evident with the standard IHC conditions. However, when using lower amounts of the antibody, a difference in the intensity of the CYP3A5 signal could be appreciated between $C Y P 3 A 5 * 1 / * 3$ and $C Y P 3 A 5 * 3 / * 3$ samples (Supplementary Fig. 1, which can be viewed online at $\mathrm{http} / / / \mathrm{erc}$.endocrinology-journals.org/supplemental/). This data implies that since CYP3A5 protein and mRNA quantifications were performed using extracts from total prostate tissue (including stromal, luminal, and basolateral cells), but only the basolateral

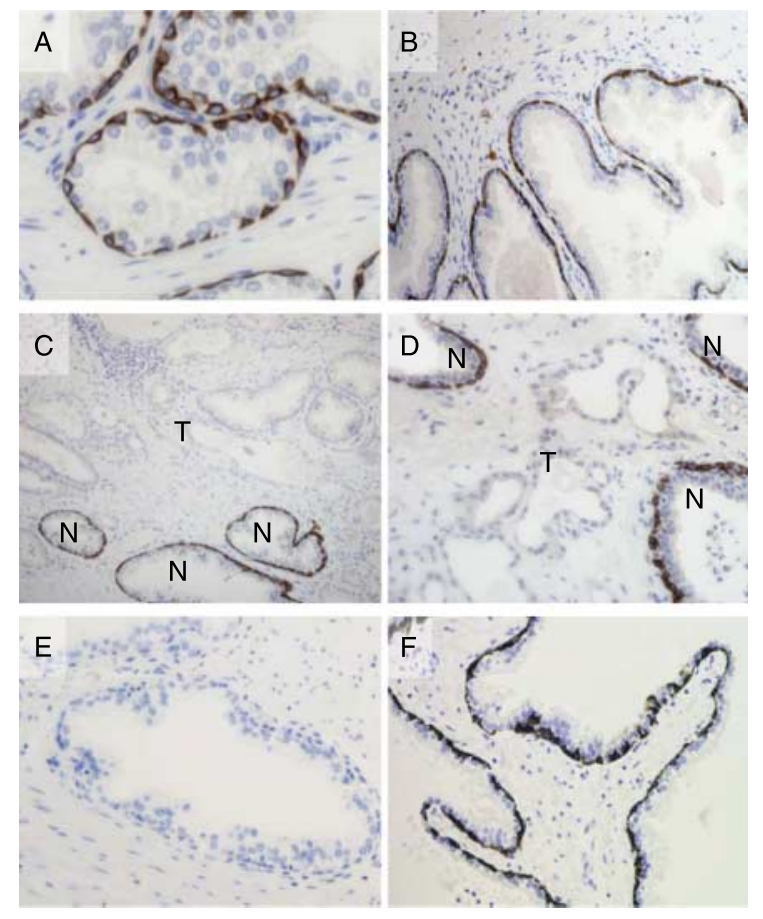

Figure 3 CYP3A5 protein detection by immunohistochemistry in prostate non-tumoral and tumoral tissue. Immunohistochemical staining of CYP3A5 was performed in paraffin sections as described in Materials and methods section. In the non-tumoral tissue (A and B) CYP3A5 was localized in the prostate glands, specifically in the basolateral cells of CYP $3 A 5^{\star} 1 /{ }^{*} 3(143 \mathrm{~N}, \mathrm{~A})$ and $C Y P 3 A 5^{\star} 3 /{ }^{*} 3(169 \mathrm{~N}, \mathrm{~B})$ samples. Immunohistochemical staining of CYP3A5 in paraffin sections of tumoral prostate samples (C and D) showed that CYP3A5 was absent in the tumoral areas (T) and CYP3A5 signal was localized only in the surrounding normal tissue $(\mathrm{N})$. The tumor samples analyzed were: 143T (C), 169T (D). (E) shows the same immunohistochemical staining procedure in $143 \mathrm{~N}$ but without CYP3A5 antibody and (F) corresponds to an IHC staining using the basolateral marker cytokeratin $34 \beta E 12$. Original magnification $\times 20$, except for $A$ with $\times 10$ and for $B$ with $\times 40$. cells contribute to CYP3A5 expression, the actual CYP3A5 levels of the basolateral cells must be higher than the calculated $15-25 \%$ of hepatic mRNA levels and $0.15 \mathrm{pmol} / \mathrm{mg}$ microsomal protein.

\section{Tumoral prostate tissue lacks CYP3A5 expression}

When we investigated the expression of CYP $3 A 5$ in the ten matched non-tumoral samples by IHC, we found that in all of them there was a complete lack of CYP3A5 protein in the tumoral areas of the tissue and that only the surrounding areas containing non-tumoral normal glands showed CYP3A5 staining (Fig. 3C and D). The lack of CYP3A5 expression in the tumor is consistent with its basolateral localization, since prostate tumors lack basal cells. To confirm this, we analyzed the expression of the basolateral marker $34 \beta \mathrm{E} 12$ and found it absent, similarly to CYP3A5, in the prostate cancer regions (data not shown). The lack of CYP3A5 expression in the tumoral areas was confirmed in 25 additional prostate cancer samples (data not shown). Analysis of the ten matched non-tumoral/tumoral samples by RT-PCR confirmed the IHC results, and we found that CYP3A5 mRNA was significantly lower in the tumoral tissue (in average 61- and 19-fold difference for total and correctly spliced CYP3A5 mRNA respectively; Supplementary Table 2). The detection of some CYP3A5 mRNA by RT-PCR in the tumoral samples can be easily explained by the contribution of contaminating non-tumoral tissue (see Fig. 3C and D). Therefore, the CYP3A5 RT-PCR and the IHC data are in full agreement.

\section{Discussion}

Contradictory and incomplete results have been reported with respect to the expression of the CYP3A enzymes in prostate tissue (Murray et al. 1995a, Finnstrom et al. 2001, Stamey et al. 2001, Koch et al. 2002, Di Paolo et al. 2005, Zhang et al. 2006, Moilanen et al. 2007). In this work, we clearly show that of the four human CYP3A enzymes only CYP3A5 had a relevant expression in prostate, with mRNA contents similar to liver (Fig. 1). Specifically, when comparing the CYP3A5 mRNA content of liver samples with prostate samples with the same CYP3A5 genotype, the prostate samples showed about $20 \%$ of the hepatic levels (Fig. 2A). Among the prostate samples included in this study, there was a large CYP3A5 mRNA variation, mainly caused by $C Y P 3 A 5 * 3$ polymorphism, which introduces an alternative splicing site that in the liver decreases the amount of full-coding transcript and 
ultimately causes low CYP3A5 protein expression (Kuehl et al. 2001). In this work, CYP3A $5 * 1 / * 3$ prostate samples had 13-fold higher amounts of correctly spliced mRNA than $C Y P 3 A 5 * 3 / * 3$ samples and, although the number of samples analyzed was small and the correlation with mRNA levels was not strong, the highest CYP3A5 protein content also corresponded to CYP3A $5 * 1 / * 3$ prostate samples (Fig. 2B). Recently, Moilanen et al. (2007) detected CYP3A5 protein in the prostate, but surprisingly CYP $3 A 5 * 3 / * 3$ samples showed similar or even higher CYP3A5 protein content than $C Y P 3 A 5 * 1 / * 3$ samples, and by IHC they found CYP3A5 protein both in luminal and basolateral cells and both in non-tumoral and tumoral prostate tissues. In contrast, in this work we found that CYP3A5 was exclusively expressed in the basolateral cells of the non-tumoral tissue (Fig. 3A and B), while absent in the tumor (Fig. 3C and D). This data were fully supported by the quantitative RT-PCR analysis in the matched non-tumoral/tumoral samples (Supplementary Table 2). The differences between this and other studies are probably caused by the use of antibodies with low specificity (e.g., CYP3A5 IHC signal by Moilanen et al. was also localized in the nuclei) which is not in agreement with the microsomal localization of CYP3A5 (compare with Fig. 3A) and in the case of mRNA by the use, in some studies, of nonquantitative PCR methods.

Because CYP3A5 protein is exclusively localized in the basolateral cells, and these represent $2 \%$ of the total prostate cells (Liu et al. 1997) about 7.5 pmol CYP3A5/mg microsomal basolateral protein can be estimated, which is similar to the $37 \mathrm{pmol}$ found in $C Y P 3 A 5 * 1 / * 3$ livers (Liu et al. 1997, Westlind-Johnsson et al. 2003). Similarly, if we take into account that only the basolateral cells contribute to CYP3A5 expression, the CYP3A5 mRNA levels in the prostate basal cells would be ten times higher than that in the liver cells. The difference between the prostatic and hepatic CYP3A5 mRNA and protein contents could indicate a tissue-specific CYP $3 A 5$ posttranscriptional regulation. In any case, the high CYP3A5 prostatic expression suggests that CYP3A5 may play a relevant function in the prostate and, since the prostate is not a tissue relevant for drug metabolism, this function must be related to the metabolism of prostatic endogenous CYP3A5 substrates, such as androgens (Ohmori et al. 1998, Miller et al. 2004). In other tissues CYP3A5 has also been shown to play an important endogenous function, and $C Y P 3 A 5 * 3$ has been shown to influence the systolic blood and pulse pressure, presumably by altering CYP3A5-mediated glucocorticoid metabolism (Kreutz et al. 2005). Thus, by oxidation of testosterone and DHEA in the basolateral prostate cells,
CYP3A5 could control their entrance into the luminal cells which grow in a hormone-dependent manner (Masai et al. 1990). In fact, androgens up-regulate CYP3A5 expression in human prostate, suggesting an autoregulatory loop to control testosterone exposure (Moilanen et al. 2007). Consequently, polymorphism affecting CYP3A5 activity could alter the oxidation of androgens in the basolateral cells and ultimately luminal prostate cell growth function and prostate cancer development (Parnes et al. 2005, Zhenhua et al. 2005).

In line with this idea, several publications have associated CYP3A SNPs with prostate cancer risk and aggressiveness (Rebbeck et al. 1998, Paris et al. 1999, Plummer et al. 2003, Loukola et al. 2004, Zhenhua et al. 2005, Bangsi et al. 2006). However, most studies have focused on $C Y P 3 A 4 * 1 B$, which does not result in major changes in CYP3A4 expression (Rodriguez-Antona et al. 2005) and is not expressed in the prostate (Fig. 1). The CYP3A locus shows a high degree of linkage disequilibrium (Kuehl et al. 2001, Lee et al. 2003), and $\sim 80 \%$ of Caucasians carrying $C Y P 3 A 4 * 1 B$ are simultaneously $C Y P 3 A 5^{*} 1$ (Wojnowski et al. 2002). In Asians, in which $C Y P 3 A 4 * 1 B$ is absent and, thus, is not a confounding factor, $C Y P 3 A 5 * 1 / * 1$ men had a 0.23 -fold lower risk of developing a low-grade prostate cancer and a 0.31 -fold lower risk of developing localized prostate cancer than $C Y P 3 A 5 * 3 / * 3$ men (Zhenhua et al. 2005). In Africans, in addition to $C Y P 3 A 5 * 3$, there are two other common functional $C Y P 3 A 5$ polymorphisms which have not been taken into account in any of the association studies carried out so far: $C Y P 3 A 5^{*} 6$, which creates an alternative splicing site similarly to $C Y P 3 A 5 * 3$, and CYP $3 A 5^{*} 7$ which has a single nucleotide insertion causing a frameshift and early stop codon (with 13 and $10 \%$ frequency respectively; Hustert et al. 2001, Kuehl et al. 2001, Lee et al. 2003). Therefore, the association studies in Africans can only be complete when all three CYP3A5 defective alleles are considered together and compared with the wild-type $C Y P 3 A 5^{*} 1$ allele. Undoubtedly, further studies are needed to confirm the association of CYP3A5 functional SNPs with prostate cancer.

In conclusion, we have shown that only $C Y P 3 A 5$ out of the four $C Y P 3 A$ genes is expressed at high levels in the non-tumoral prostate tissue, specifically in the basolateral cells and that this expression does not occur in the tumors. This data reveal an important endogenous role of CYP3A5 in the prostate and association studies between prostate cancer and CYP3A polymorphisms indicate that this function must be related to the metabolism of intra-prostatic androgens and regulation of luminal cell growth. Furthermore, this data suggest that future prostate cancer association 
studies on $C Y P 3 A$ genes should focus on CYP3A5 functional polymorphisms such as $C Y P 3 A 5^{*} 3$, *6, and $* 7$ which could be directly associated with prostate cancer risk and aggressiveness.

\section{Acknowledgements}

The authors thank Lydia Sanchez and the CNIO Immunohistochemical Unit for expert technical assistance. Tissue samples were provided by the Tissue Bank Network coordinated by the Molecular Pathology Program of the Spanish National Cancer Centre (CNIO), with the collaboration of the Tumor Bank of the Department of Pathology, Universitary Hospital Virgen de las Nieves from Granada, Spain.

This study was supported by Cristina RodríguezAntona's Marie Curie Reintegration Fellowship of the European Community contract number MERG-CG-62005-014881, project SAF2006-01139 and the 'Ramon y Cajal' program both from the Spanish Ministry of Education and Science. Susanna Leskelä has a fellowship from the Spanish Ministry of Education and Science AP2005-4514. The authors declare that there is no conflict of interest that would prejudice the impartiality of this scientific work.

\section{References}

Bangsi D, Zhou J, Sun Y, Patel NP, Darga LL, Heilbrun LK, Powell IJ, Severson RK \& Everson RB 2006 Impact of a genetic variant in CYP3A4 on risk and clinical presentation of prostate cancer among white and AfricanAmerican men. Urologic Oncology 24 21-27.

Burk O, Tegude H, Koch I, Hustert E, Wolbold R, Glaeser H, Klein K, Fromm MF, Nuessler AK, Neuhaus P et al. 2002 Molecular mechanisms of polymorphic CYP3A7 expression in adult human liver and intestine. Journal of Biolgical Chemistry 277 24280-24288.

Domanski TL, Finta C, Halpert JR \& Zaphiropoulos PG 2001 cDNA cloning and initial characterization of CYP3A43, a novel human cytochrome P450. Molecular Pharmacology 59 386-392.

Feldman BJ \& Feldman D 2001 The development of androgen-independent prostate cancer. Nature Reviews Cancer $134-45$.

Finnstrom N, Bjelfman C, Soderstrom TG, Smith G, Egevad L, Norlen BJ, Wolf CR \& Rane A 2001 Detection of cytochrome P450 mRNA transcripts in prostate samples by RT-PCR. European Jouranl of Clinical Investigation 31 880-886.

Hustert E, Haberl M, Burk O, Wolbold R, He YQ, Klein K, Nuessler AC, Neuhaus P, Klattig J, Eiselt R et al. 2001 The genetic determinants of the CYP3A5 polymorphism. Pharmacogenetics 11 773-779.
Kamdem LK, Meineke I, Koch I, Zanger UM, Brockmoller J \& Wojnowski L 2004 Limited contribution of CYP3A5 to the hepatic 6beta-hydroxylation of testosterone. NaunynSchmiedeberg's Archives of Pharmacology 370 71-77.

Koch I, Weil R, Wolbold R, Brockmoller J, Hustert E, Burk $\mathrm{O}$, Nuessler A, Neuhaus P, Eichelbaum M, Zanger U et al. 2002 Interindividual variability and tissue-specificity in the expression of cytochrome P450 3A mRNA. Drug Metabolism and Disposition 30 1108-1114.

Kreutz R, Zuurman M, Kain S, Bolbrinker J, de Jong PE \& Navis G 2005 The role of the cytochrome P450 3A5 enzyme for blood pressure regulation in the general Caucasian population. Pharmacogenetics and Genomics 15 831-837.

Kuehl P, Zhang J, Lin Y, Lamba J, Assem M, Schuetz J, Watkins PB, Daly A, Wrighton SA, Hall SD et al. 2001 Sequence diversity in CYP3A promoters and characterization of the genetic basis of polymorphic CYP3A5 expression. Nature Genetics 27 383-391.

Lee SJ, Usmani KA, Chanas B, Ghanayem B, Xi T, Hodgson E, Mohrenweiser HW \& Goldstein JA 2003 Genetic findings and functional studies of human CYP3A5 single nucleotide polymorphisms in different ethnic groups. Pharmacogenetics 13 461-472.

Li AP, Kaminski DL \& Rasmussen A 1995 Substrates of human hepatic cytochrome P450 3A4. Toxicology 104 1-8.

Lin YS, Dowling AL, Quigley SD, Farin FM, Zhang J, Lamba J, Schuetz EG \& Thummel KE 2002 Co-regulation of CYP3A4 and CYP3A5 and contribution to hepatic and intestinal midazolam metabolism. Molecular Pharmacology 62 162-172.

Liu AY, True LD, LaTray L, Nelson PS, Ellis WJ, Vessella RL, Lange PH, Hood L \& van den Engh G 1997 Cell-cell interaction in prostate gene regulation and cytodifferentiation. PNAS 94 10705-10710.

Loukola A, Chadha M, Penn SG, Rank D, Conti DV, Thompson D, Cicek M, Love B, Bivolarevic V, Yang Q et al. 2004 Comprehensive evaluation of the association between prostate cancer and genotypes/haplotypes in CYP17A1, CYP3A4, and SRD5A2. European Journal of Human Genetics 12 321-332.

Makridakis N, Ross RK, Pike MC, Chang L, Stanczyk FZ, Kolonel LN, Shi CY, Yu MC, Henderson BE \& Reichardt JK 1997 A prevalent missense substitution that modulates activity of prostatic steroid 5alpha-reductase. Cancer Research 57 1020-1022.

Makridakis NM, Ross RK, Pike MC, Crocitto LE, Kolonel LN, Pearce CL, Henderson BE \& Reichardt JK 1999 Association of mis-sense substitution in SRD5A2 gene with prostate cancer in AfricanAmerican and Hispanic men in Los Angeles, USA. Lancet 354 975-978.

Masai M, Sumiya H, Akimoto S, Yatani R, Chang CS, Liao SS \& Shimazaki J 1990 Immunohistochemical study of androgen receptor in benign hyperplastic and cancerous human prostates. Prostate 17 293-300. 
McNeal JE, Price HM, Redwine EA, Freiha FS \& Stamey TA 1988a Stage A versus stage B adenocarcinoma of the prostate: morphological comparison and biological significance. Journal of Urology 139 61-65.

McNeal JE, Redwine EA, Freiha FS \& Stamey TA $1988 b$ Zonal distribution of prostatic adenocarcinoma. Correlation with histologic pattern and direction of spread. American Journal of Surgical Pathology 12 897-906.

McNeal JE 1969 Origin and development of carcinoma in the prostate. Cancer 23 24-34.

McNeal JE 1978 Origin and evolution of benign prostatic enlargement. Investigative Urology 15 340-345.

Miller KK, Cai J, Ripp SL, Pierce WM Jr, Rushmore TH \& Prough RA 2004 Stereo- and regioselectivity account for the diversity of dehydroepiandrosterone (DHEA) metabolites produced by liver microsomal cytochromes P450. Drug Metabolism and Disposition 32 305-313.

Moilanen AM, Hakkola J, Vaarala MH, Kauppila S, Hirvikoski P, Vuoristo JT, Edwards RJ \& Paavonen TK 2007 Characterization of androgen-regulated expression of CYP3A5 in human prostate. Carcinogenesis 28 916-921.

Murray GI, Pritchard S, Melvin WT \& Burke MD $1995 a$ Cytochrome P450 CYP3A5 in the human anterior pituitary gland. FEBS Letters 364 79-82.

Murray GI, Taylor VE, McKay JA, Weaver RJ, Ewen SW, Melvin WT \& Burke MD $1995 b$ The immunohistochemical localization of drug-metabolizing enzymes in prostate cancer. Journal of Pathology 177 147-152.

Novelli G, Margiotti K, Chiocca AM, Spera E, Micali F \& Reichardt JK 2004 Pharmacogenetics of human androgens and prostate cancer-an update. Pharmacogenomics 5 283-294.

Ohmori S, Nakasa H, Asanome K, Kurose Y, Ishii I, Hosokawa M \& Kitada M 1998 Differential catalytic properties in metabolism of endogenous and exogenous substrates among CYP3A enzymes expressed in COS-7 cells. Biochimica et Biophysic Acta 1380 297-304.

Di Paolo OA, Teitel CH, Nowell S, Coles BF \& Kadlubar FF 2005 Expression of cytochromes P450 and glutathione S-transferases in human prostate, and the potential for activation of heterocyclic amine carcinogens via acetylcoA-, PAPS- and ATP-dependent pathways. International Journal of Cancer 117 8-13.

Paris PL, Kupelian PA, Hall JM, Williams TL, Levin H, Klein EA, Casey G \& Witte JS 1999 Association between a CYP3A4 genetic variant and clinical presentation in African-American prostate cancer patients. Cancer Epidemiology, Biomarkers \& Prevention 8 901-905.

Park J, Chen L, Ratnashinge L, Sellers TA, Tanner JP, Lee JH, Dossett N, Lang N, Kadlubar FF, Ambrosone CB et al. 2006 Deletion polymorphism of UDP-glucuronosyltransferase
2B17 and risk of prostate cancer in African American and Caucasian men. Cancer Epidemiology, Biomarkers \& Prevention 15 1473-1478.

Parnes HL, Thompson IM \& Ford LG 2005 Prevention of hormone-related cancers: prostate cancer. Journal of Clinical Oncology 23 368-377.

Plummer SJ, Conti DV, Paris PL, Curran AP, Casey G \& Witte JS 2003 CYP3A4 and CYP3A5 genotypes, haplotypes, and risk of prostate cancer. Cancer Epidemiology, Biomarkers and Prevention 12 928-932.

Rebbeck TR, Jaffe JM, Walker AH, Wein AJ \& Malkowicz SB 1998 Modification of clinical presentation of prostate tumors by a novel genetic variant in CYP3A4. Journal of National Cancer Institute 90 1225-1229.

Rodriguez-Antona C \& Ingelman-Sundberg M 2006 Cytochrome P450 pharmacogenetics and cancer. Oncogene 25 1679-1691.

Rodriguez-Antona C, Sayi JG, Gustafsson LL, Bertilsson L \& Ingelman-Sundberg M 2005 Phenotype-genotype variability in the human CYP3A locus as assessed by the probe drug quinine and analyses of variant CYP3A4 alleles. Biochemical and Biophysical Research Communications 338 299-305.

Sim SC, Edwards RJ, Boobis AR \& Ingelman-Sundberg M 2005 CYP3A7 protein expression is high in a fraction of adult human livers and partially associated with the CYP3A7*1C allele. Pharmacogenetics and Genomics 15 625-631.

Stamey TA, Warrington JA, Caldwell MC, Chen Z, Fan Z, Mahadevappa M, McNeal JE, Nolley R \& Zhang Z 2001 Molecular genetic profiling of Gleason grade $4 / 5$ prostate cancers compared to benign prostatic hyperplasia. Journal of Urology 166 2171-2177.

Thompson EE, Kuttab-Boulos H, Witonsky D, Yang L, Roe BA \& Di Rienzo A 2004 CYP3A variation and the evolution of salt-sensitivity variants. American Journal of Human Genetics 75 1059-1069.

Thompson EE, Kuttab-Boulos H, Yang L, Roe BA \& Di Rienzo A 2006 Sequence diversity and haplotype structure at the human CYP3A cluster. Pharmacogenomics Journal 6 105-114.

Thummel KE \& Wilkinson GR 1998 In vitro and in vivo drug interactions involving human CYP3A. Annual Review of Pharmacology and Toxicology 38 389-430.

Villers A, Steg A \& Boccon-Gibod L 1991 Anatomy of the prostate: review of the different models. European Urology 20 261-268.

Westlind A, Malmebo S, Johansson I, Otter C, Andersson TB, Ingelman-Sundberg M \& Oscarson M 2001 Cloning and tissue distribution of a novel human cytochrome p450 of the CYP3A subfamily, CYP3A43. Biochemical and Biophysical Research Communications 281 1349-1355.

Westlind-Johnsson A, Malmebo S, Johansson A, Otter C, Andersson TB, Johansson I, Edwards RJ, Boobis AR \& Ingelman-Sundberg M 2003 Comparative analysis of 
CYP3A expression in human liver suggests only a minor role for CYP3A5 in drug metabolism. Drug Metabolism and Disposition 31 755-761.

Wojnowski L, Hustert E, Klein K, Goldammer M, Haberl M, Kirchheiner J, Koch I, Klattig J, Zanger U \& Brockmoller J 2002 Re: modification of clinical presentation of prostate tumors by a novel genetic variant in CYP3A4. Journal of National Cancer Institute 94 630-631.
Zhang W, Shannon WD, Duncan J, Scheffer GL, Scheper RJ \& McLeod HL 2006 Expression of drug pathway proteins is independent of tumour type. Journal of Pathology 209 213-219.

Zhenhua L, Tsuchiya N, Narita S, Inoue T, Horikawa Y, Kakinuma H, Kato T, Ogawa O \& Habuchi T 2005 CYP3A5 gene polymorphism and risk of prostate cancer in a Japanese population. Cancer Letters 225 237-243. 